\title{
Reflectance confocal microscopy as a tool for screening surgical margins of basal cell carcinoma*
}

\author{
Danilo Augusto Teixeira ${ }^{1,2}$, Gisele Gargantini Rezze 3 , Maria Aparecida Silva Pinhal ${ }^{4}$, \\ Francisco Macedo Paschoal ${ }^{5}$
}

DOI: http:/ / dx.doi.org/10.1590/abd1806-4841.20187089

\begin{abstract}
Surgical excision of basal cell carcinoma with minimum margins requires serial assessment of layers by frozen histopathology in the case of Mohs micrographic surgery. Evaluation of presurgical tumor margins by in vivo reflectance confocal microscopy is a potential alternative. We selected 12 basal cell carcinoma lesions that were analyzed by confocal microscopy to define margins. The lesions were excised by Mohs surgery. Six tumors showed negative margins in the first phase of Mohs micrographic surgery. We concluded that reflectance confocal microscopy can be useful in the preoperative definition of basal cell carcinoma margins.
\end{abstract}

Keywords: Carcinoma, basal cell; Microscopy, confocal; Mohs surgery

The incidence of basal cell carcinoma (BCC) is increasing steadily in most countries, accounting for $80 \%$ of all non-melanoma skin cancers. ${ }^{1}$ The primary goal of dermatologic surgery for the treatment of skin cancer is complete tumor removal with safety margins, thus avoiding persistence and recurrence. ${ }^{2}$

Mohs micrographic surgery (MMS) is considered the most efficient technique for excision of high-risk BCCs. ${ }^{1,2}$ The procedure uses microscopic analysis of frozen fragments of the tumor margins during surgery, ${ }^{3,4}$ Multiple serial excisions are often necessary to achieve free margins, which makes the procedure highly time-consuming and laborious. ${ }^{1-5}$

Some non-invasive techniques for determining in vivo tumor margins have been proposed to reduce time and costs. ${ }^{2}$ Among them, reflectance confocal microscopy (RCM) is proving to be an efficient method for detection of lateral margins in BCC lesions, owing to its ability to explore the skin at the cellular level. ${ }^{2}$

Some studies have confirmed that RCM provides excellent sensitivity and specificity in BCC diagnosis. ${ }^{1,6}$ In RCM, the contrast is achieved due to the difference in the refractive indices of cell structures and organelles ("endogenous chromophores"). ${ }^{3}$ Because it allows observation of cellular morphology of excised skin fragments in real time, ex vivo RCM is an attractive alternative to frozen histopathology during MMS., ${ }^{3,7}$

RCM is being used in vivo as an instrument to determine tumor margins prior to MMS. However, its use is limited to the investigation of lateral margins and not the deep tumor area due to

\footnotetext{
Received 15 March 2017.

Accepted 29 October 2017

* Work conducted at the Faculdade de Medicina do ABC, Santo André (SP), Brazil.

Financial Support: None.

Conflict of interests: None.

Graduate Master's Program in Health Sciences, Faculdade de Medicina do ABC, Santo André (SP), Brazil.

Outpatient Clinic for Dermatological Surgery of the Medical Residency Program, Hospital de Doenças Tropicais, Goiânia (GO), Brazil

Graduate Studies Program in Oncology, Fundação Antônio Prudente, São Paulo (SP), Brazil.

Course in Biochemistry, Faculdade de Medicina do ABC, Santo André (SP), Brazil.

Course in Dermatology, Faculdade de Medicina do ABC, Santo André (SP), Brazil.

MAILING AdDREsS:

Danilo Augusto Teixeira

E-mail: danilocotoh@yahoo.com.br 
its limited visualization of the deep dermis., ${ }^{3,8}$ Pan et al. have used RCM to determine superficial and nodular BCC margins and have reached positive results with free margins in $92.3 \%$ of their cases. ${ }^{1}$

The objective of this study was to evaluate the effectiveness of RCM for preoperative determination of surgical margins in BCC prior to performing MMS.

The study was approved by the Institutional Review Board and was conducted in accordance with the Declaration of Helsinki. We selected eight patients with 12 lesions with histopathologically proven diagnosis of $\mathrm{BCC}$ measuring less than $1 \mathrm{~cm}$ on the long axis.

Lesions underwent imaging using a near-infrared reflectance confocal laser microscope (Vivascope 1500; Caliber I.D., Rochester, NY, USA), which uses a diode laser with a wavelength of 830 $\mathrm{nm}$. A minimum of 3 mosaics were obtained per lesion, one at the superficial epidermal layer, one at the dermal-epidermal junction, and another at the papillary dermal level, each mosaic containing $16 \times 16$ images of 500x500 $\mu \mathrm{m}$. RCM images can be obtained to a depth of approximately $300 \mu \mathrm{m}$ within tissue. ${ }^{8}$ The RCM criteria used for diagnosis and determination of BCC limits were: presence of tumor islands, clefts, dark silhouettes, peripheral palisading, canalicular vessels, inflammatory cells, and thick collagen. . 1,39 $^{2}$
After confocal microscopic examination, the peripheral borders were traced and marked on the patient's skin with a surgical pen. Once the margins were outlined, the lesions were excised using the MMS technique. The first step in MMS was performed with a 2 $\mathrm{mm}$ margin, followed by evaluation of the presence or absence of tumor involvement in the lateral and deep margins in the respective frozen sections. The surgery was considered complete when there were no positive margins.

In RCM, we have observed tumor islands and clefts in most tumors. Inflammatory cells, microcirculation in the tumor periphery, and dark silhouettes have also helped in the identification and determination of all tumor margins (Table 1).

Following the first phase of MMS, six tumors (50\%) showed positive margins. Nevertheless, in four cases the margins' involvement was less than $10 \%$ (Table 1). For these tumors, a second MMS stage was necessary for total excision of the BCC. Six lesions (50\%) had negative margins after the first phase of MMS (Table 1, Figure 1).

BCC is the most common skin tumor and often occurs in sun-exposed areas. Many treatment options are available, and choosing the best method depends on location, histology, tumor size, and comorbidities. ${ }^{8}$ RCM has been used for the presurgical

\begin{tabular}{|c|c|c|c|c|c|c|}
\hline Lesion & $\begin{array}{l}\text { BCC Subtype } \\
\text { (histology) }\end{array}$ & Location & $\begin{array}{l}\text { Clinical size } \\
(\mathrm{mm})\end{array}$ & RCM features & $\begin{array}{c}\text { Commitment of } \\
\text { margins } \\
\text { (percentage) }\end{array}$ & $\begin{array}{l}\text { Number of } \\
\text { MMS phases }\end{array}$ \\
\hline 1 & Micronodular & Nasal dorsum & $4 \times 3$ & $\begin{array}{l}\text { Presence of tumor islands, } \\
\text { clefts, inflammatory cells and } \\
\text { microvasculature in the tumor } \\
\text { periphery extending beyond } \\
\text { the tumor stromal }\end{array}$ & $\begin{array}{c}\text { Deep and lateral } \\
\text { margin }(<10 \%)\end{array}$ & 2 \\
\hline 2 & Nodular & Left Cheek & $7 \times 6$ & $\begin{array}{l}\text { Small tumor islands wrapped } \\
\text { in fibrous tissue } \\
\text { Scattered inflammatory cells }\end{array}$ & $\begin{array}{l}\text { Lateral margin } \\
\qquad(<5 \%)\end{array}$ & 2 \\
\hline 3 & Nodular & Left forearm & $7 \times 7$ & Tumor islands and clefts & Deep margin $(<5 \%)$ & 2 \\
\hline 4 & Micronodular & Right arm & $7 \times 7$ & Tumor islands and clefts & $\begin{array}{l}\text { Deep margin } \\
(<20 \%)\end{array}$ & 2 \\
\hline 5 & Nodular & Chin & $8 \times 8$ & Tumor islands and clefts & $\begin{array}{l}\text { Deep margin } \\
\quad(<30 \%)\end{array}$ & 2 \\
\hline 6 & Nodular & Upper lip & $7 \times 7$ & $\begin{array}{l}\text { Tumor islands, dark silhou- } \\
\text { ettes, scattered inflammatory } \\
\text { cells }\end{array}$ & Free margins & 1 \\
\hline 7 & Micronodular & Left scapula & $8 \times 7$ & Tumor islands and clefts & $\begin{array}{l}\text { Lateral margin } \\
\qquad(<5 \%)\end{array}$ & 2 \\
\hline 8 & Micronodular & Right scapula & $6 \times 5$ & Tumor islands and clefts & Free Margins & 1 \\
\hline 9 & $\begin{array}{l}\text { Micronodular } \\
\text { and scleroder- } \\
\text { miform }\end{array}$ & Forehead & $6 \times 3$ & $\begin{array}{l}\text { Tumor islands and clefts, scat- } \\
\text { tered inflammatory cells and } \\
\text { microvasculature }\end{array}$ & Free margins & 1 \\
\hline 10 & Nodular & Forehead & $6 \times 5$ & $\begin{array}{l}\text { Tumor islands and clefts, scat- } \\
\text { tered inflammatory cells and } \\
\text { microvasculature }\end{array}$ & Free margins & 1 \\
\hline 11 & Micronodular & $\begin{array}{l}\text { Left } \\
\text { retroauricular }\end{array}$ & $8 \times 8$ & $\begin{array}{l}\text { Small tumor islands wrapped } \\
\text { in fibrous tissue }\end{array}$ & Free margins & 1 \\
\hline
\end{tabular}



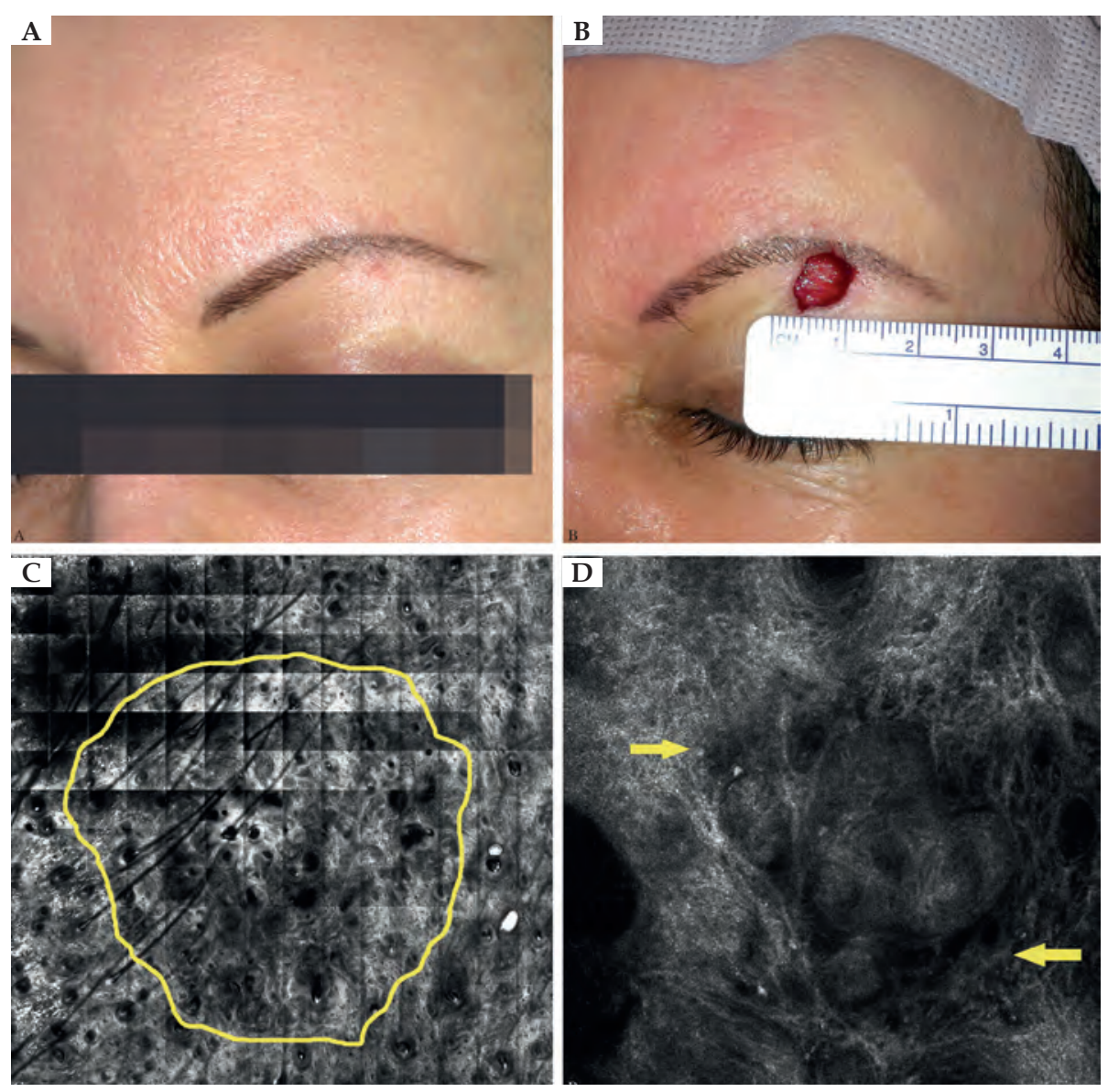

FiguRe 1: A 50 year-old female patient presenting with erythematous lesion on left brow, with imprecise limits and unspecific vascular pattern on dermatoscopic examination (A). Removal of lesion with additional margin of $2 \mathrm{~mm}$ beyond the margins set by confocal microscopy (B). On confocal microscopy, tumor islands and clefts were observed (arrow), suggesting the diagnosis of basal cell carcinoma with approximate $5 \times 4.5 \mathrm{~mm}$ on long axis dimensions (C and D)

analysis of tumor margins, although its use is limited to assessment of the lateral rather than the deep tumor margins. ${ }^{8}$

Pan et al., in a series of 13 cases, showed the applicability of RCM in determining presurgical margins, with only one failure (deep margin), and they thus suggested the use of this method by Mohs surgeons. ${ }^{1}$

RCM ex vivo is an alternative to frozen histopathology during Mohs surgery, since BCC margins can be observed directly and in real time in freshly excised tissue., ${ }^{3,70}$ This new technique's main advantages are less time spent on preparing images and lower cost. $^{7}$
Although RCM may enable tumor identification with high accuracy, there is some difficulty in finding an efficient methodology that allows converting the margins seen on RCM to the skin. ${ }^{2}$ Once the RCM is disengaged and the metal ring removed from the skin, the exact position of the area identified on RCM images cannot be precisely detected on the skin. ${ }^{2}$ This difficulty and the device limitations in visualizing tumor depth margins could explain the positive margins in the first stage of MMS in six cases.

Although only six cases (50\%) showed free margins in the first stage of MMS, RCM allowed complete definition of the tumor's lateral borders in all the cases, leading to preservation of healthy skin. $\square$ 


\section{REFERENCES}

1. Pan ZY, Lin JR, Cheng TT, Wu JQ, Wu WY. In vivo reflectance confocal microscopy of basal cell carcinoma: feasibility of preoperative mapping of cancer margins Dermatol Surg. 2012;38:1945-50.

2. Venturini M, Gualdi G, Zanca A, Lorenzi L, Pellacani G, Calzavara-Pinton PG. A new approach for pre-surgical margin assessment of basal cell carcinoma by reflectance confocal microscopy. Br J Dermatol. 2016;174:380-5.

3. Longo C, Ragazzi M, Rajadhyaksha M, Nehal K, Bennassar A, Pellacani G, et al. In vivo and ex vivo confocal microscopy for dermatologic and Mohs surgeons. Dermatol Clin. 2016;34:497-504.

4. Gareau DS, Jeon H, Nehal KS, Rajadhyaksha M. Rapid screening of cancer margins in tissue with multimodal confocal microscopy. J Surg Res. 2012;178:533-8.

5. Gareau DS, Patel YG, Li Y, Aranda I, Halpern AC, Nehal KS, et al. Confoca mosaicing microscopy in skin excisions: a demonstration of rapid surgical pathology. J Microsc. 2009;233:149-59.
6. Ulrich M, Lange-Asschenfeldt S, González S. In vivo reflectance confocal microscopy for early diagnosis of nonmelanoma skin câncer. Actas Dermosifiliogr. 2012;103:784-9.

7. Bennàssar $\mathrm{A}$, Vilata $\mathrm{A}$, Puig $\mathrm{S}$, Malvehy J. Ex vivo fluorescence confocal microscopy for fast evaluation of tumour margins during Mohs surgery. $\mathrm{Br} J$ Dermatol. 2014;170:360-5

8. Longo C, Ragazzi M, Castagnetti F, Gardini S, Palmieri T, Lallas A, et al. Inserting ex vivo fluorescence confocal microscopy perioperatively in Mohs micrographic surgery expedites bedside assessment of excision margins in recurrent basal cell carcinoma. Dermatology. 2013;227:89-92.

9. Scope A, Mahmood U, Gareau DS, Kenkre M, Lieb JA, Nehal KS, et al. In vivo reflectance confocal microscopy of shave biopsy wounds: feasibility of intraoperative mapping of cancer margins. Br J Dermatol. 2010;163:1218-28.

10. Larson B, Abeytunge S, Seltzer E, Rajadhyaksha M, Nehal K. Detection of skin cancer margins in Mohs excisions with high-speed strip mosaicing confocal microscopy: a feasibility study. Br J Dermatol. 2013;169:922-6.

\section{AUTHORS CONTRIBUTION}

$\begin{array}{lll}\text { Danilo Augusto Teixeira } & \text { (iD) ORCID } & 0000-0001-7629-7777\end{array}$

Statistical analysis; Approval of the final version of the manuscript; Conception and planning if the study; Elaboration and writing of the manuscript; Obtaining, analyzing and interpreting the data; Effective participation in research orientation; Intellectual par of the literature; Critical review of the manuscript

Gisele Gargantini Rezze

$$
\text { (iD) ORCID 0000-0001-9084-4634 }
$$

Obtaining, analyzing and interpreting the data; Effective participation in research orientation; Intellectual participation in propaedeutic and/or therapeutic conduct of cases studied

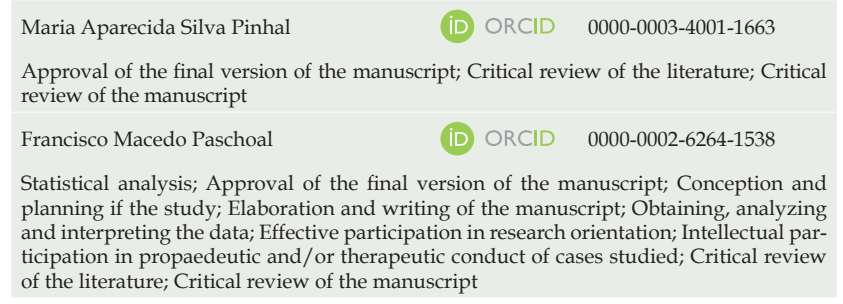

How to cite this article: Teixeira DA, Rezze GG, Pinhal MAS, Paschoal FM. Reflectance confocal microscopy as a tool for screening surgical margins of basal cell carcinoma. An Bras Dermatol. 2018;93(4):601-4. 